\title{
Effects of water temperature and pH on growth and metabolite biosynthesis of coral reef sponges
}

\author{
Alan R. Duckworth ${ }^{1,5, *}$, Lyndon West ${ }^{2}$, Tifanie Vansach ${ }^{2}$, Amber Stubler $^{3}$, \\ Marah Hardt ${ }^{4}$ \\ ${ }^{1}$ Blue Ocean Institute, Stony Brook University, New York 11794, USA \\ ${ }^{2}$ Department of Chemistry and Biochemistry, Florida Atlantic University, Florida 33431, USA \\ ${ }^{3}$ School of Marine and Atmospheric Sciences, Stony Brook University, New York 11794, USA \\ ${ }^{4}$ OceanInk, Kamuela, Hawaii 96743, USA \\ ${ }^{5}$ Present address: Australian Institute of Marine Science, Townsville, Queensland 4810, Australia
}

\begin{abstract}
Warmer, more acidic water resulting from increased emissions of greenhouse gases will impact coral reef organisms, but the effects remain unknown for many dominant groups such as sponges. To test for possible effects, adult sponges of 6 common Caribbean coral reef speciesAiolochroia crassa, Aplysina cauliformis, Aplysina fistularis, Ectyoplasia ferox, Iotrochota birotulata and Smenospongia conulosa - were grown for $24 \mathrm{~d}$ in seawater ranging from values experienced at present-day summer-maxima (temperature $=28^{\circ} \mathrm{C}_{i} \mathrm{pH}=8.1$ ) to those predicted for the year 2100 (temperature $=31^{\circ} \mathrm{C} i \mathrm{pH}=7.8$ ). For each species, growth and survival were similar among temperature and $\mathrm{pH}$ levels. Sponge attachment rates, which are important for reef consolidation, were similar between $\mathrm{pH}$ values for all species, and highest at $31^{\circ} \mathrm{C}$ for E. ferox, I. birotulata and A. cauliformis. Secondary metabolites, responsible for deterring predation and fouling, were examined for A. crassa, A. cauliformis, E. ferox and I. birotulata, with 1 to 3 major metabolites quantified from each species. Final metabolite concentrations varied significantly among treatments only for zooanemonin from $E$. ferox and $N$-tele-methylhistamine from I. birotulata, but these concentrations were similar to those found in wild conspecifics. Considering adult sponges only, these findings suggest that the ecological roles and physiological processes of the 6 coral reef species will be little affected by the mean values of water temperature and $\mathrm{pH}$ predicted for the end of the century.
\end{abstract}

KEY WORDS: Sponges · Water temperature · pH · Climate change - Growth · Metabolite biosynthesis Resale or republication not permitted without written consent of the publisher

\section{INTRODUCTION}

Global warming and ocean acidification will continue to impact coral reefs worldwide (HoeghGuldberg et al. 2007, Guinotte \& Fabry 2008) with varied effects ranging from bleaching and reduced calcification rates of some organisms (Anthony et al. 2008) to increased mortality of coral reef fish (Munday et al. 2009). Most research examining effects of climate change and ocean acidification on coral reefs has focused on corals and fishes (Przeslawski et al. 2008). However, many other organisms are ecologi- cally important to coral reefs, like sponges (Diaz \& Rützler 2001). Sponges are consumed by fish and sea turtles (Randall \& Hartman 1968, León \& Bjorndal 2002), provide refuge to juvenile animals (Butler et al. 1994), help consolidate loose rubble (Wulff 1984) and filter bacteria and phytoplankton from reef water (Reiswig 1971, Lesser 2006). Sponges can also aggressively compete for space with neighboring organisms (Porter \& Targett 1988, Aerts 1998) and some species excavate under live coral tissue, affecting coral health (Rützler 2004, López-Victoria et al. 2006). If changing water temperature and acidity lev- 
els negatively affect coral reef sponges, these ecological processes and community interactions could be impacted.

The combined effects of warmer and more acidic waters on marine sponges are largely unknown. Millions of years ago, mass extinctions of calcifying sponges occurred during periods of ocean acidification and global warming (Kiessling \& Simpson 2011). However, most coral reef sponges today are not calcifying species; instead they have a skeleton composed of silica spicules and/or spongin fibers (i.e. demosponges), so the effects today may differ from those of archaic times. Numerous studies have also found a relationship between water temperature and sponge growth and survival. Seasonal patterns of water temperature, for example, are positively correlated with sponge growth for some tropical species (e.g. McMurray et al. 2008, Leong \& Pawlik 2010, Duckworth \& Wolff 2011). In contrast, high water temperatures can exclude coral reef sponges from neighboring habitats (Pawlik et al. 2007), disrupt their symbiotic relationship with microbes, causing death (Webster et al. 2008), and promote disease outbreaks that decimate sponge populations (Smith 1941). The $\mathrm{pH}$ level can also influence sponge abundances, with low pH seawater caused by sulphur springs restricting distributions of some marine species (Southward et al. 1996). Some freshwater sponges, in contrast, grow and survive in waters ranging across 3 orders of magnitude in acidity (Jewell 1939). However, freshwater sponges live in habitats that experience greater environmental variability than the relatively constant oligotrophic conditions of coral reefs. All these studies suggest that rising water temperatures and lowering levels of $\mathrm{pH}$ could influence the growth and survival of coral reef sponges.

Environmental factors like high water temperature can also promote the attachment of sponge fragments (Barthel \& Theede 1986, Rosell \& Uriz 1992), produced through storm or predator damage (Wulff 1985). These fragments must attach quickly, otherwise they could be swept off the reef. Fragments of some sponge species also bind and stabilize loose coral rubble, and are therefore important for reef consolidation (Wulff 1984). Similar to sponge growth and survival, it is unknown what the combined effects of warmer, more acidic waters will have on the attachment rates of coral reef sponges.

All living organisms produce an enormous variety of organic molecules for a large variety of functions. Primary metabolites, such as lipids, proteins and carbohydrates are the fundamental molecules of biolog- ical function. Secondary metabolites are molecules that are not directly involved in the growth, development or reproduction of an organism; however, they are essential for survival in a competitive and continuously changing environment. The ecological roles of secondary metabolites can be difficult to identify, but often include defense against predation, encroachment and fouling (Pawlik 1993).

In sponges, metabolite biosynthesis is correlated with or influenced by several factors including water temperature. This relationship can vary among species, with high water temperature correlated with both low (e.g. Abdo et al. 2007) and high metabolite concentration (e.g. Page et al. 2005). The influence of $\mathrm{pH}$ on sponge metabolite biosynthesis is unknown, but considering possible effects of $\mathrm{pH}$ on sponge growth and abundance, it could impact metabolite concentrations. In sponges, if concentrations of secondary metabolites are too low the organism can be undefended (Lindel et al. 2000). Therefore, changing levels of water temperature and $\mathrm{pH}$ could influence a sponge's ability to defend itself.

The present study investigates the effects of water temperature and $\mathrm{pH}$ on the growth, survival, attachment and metabolite biosynthesis of several coral reef sponges: Aiolochroia crassa (Hyatt, 1875), Aplysina cauliformis (Carter, 1882), Aplysina fistularis (Pallas, 1766), Ectyoplasia ferox (Duchassaing \& Michelotti, 1864), Iotrochota birotulata (Higgin, 1877) and Smenospongia conulosa Pulitzer-Finali, 1986. All 6 species are demosponges, and represent several gross morphologies: A. cauliformis and $I$. birotulata have an upright, rope morphology, A. fistularis is a tube sponge, E. ferox is thickly encrusting, and $A$. crassa and $S$. conulosa have a massive shape. Crude organic extracts (i.e. all secondary metabolites combined) from these sponge species are found to prevent predation, overgrowth and fouling (Pawlik et al. 1995, Engel \& Pawlik 2000, Kelly et al. 2003). Ecological roles are also suggested for several secondary metabolites isolated from these sponges. For example, zooanemonin and $N$-methyl-aerophobin 2 have antifouling properties (Hattori et al. 2001, Diers et al. 2004), fistularin 3 is likely a precursor molecule for hemifisturlarin 3, which prevents fouling (Diers et al. 2004), while histamines deter fish predation (Lindel et al. 2000). All 6 sponge species are commonly found on Caribbean coral reefs at shallow depths $(<20 \mathrm{~m})$, including the north shore of Jamaica where this study occurred. Shallow water sponges were examined because they will be most affected by rising sea surface temperatures. Water temperature on Jamaican coral reefs currently averages $28.1^{\circ} \mathrm{C}$ 
(Leichter \& Genovese 2006), and will likely increase to $31^{\circ} \mathrm{C}$ by the end of this century (Sheppard \& RiojaNieto 2005) due to increased emissions of greenhouse gases such as $\mathrm{CO}_{2}$. As our oceans absorb more $\mathrm{CO}_{2}$, the average $\mathrm{pH}$ of tropical seas is predicted to decrease from 8.1 to 7.8 by 2100 (Orr et al. 2005).

\section{MATERIALS AND METHODS}

\section{Species collection}

From the fore reef at Discovery Bay, Jamaica, a portion of 6 to 8 individuals of each species was collected, leaving at least two-thirds of each individual attached to the reef to regrow (Duckworth 2003). Aiolochroia crassa has several color morphs and in this study only purple-colored individuals were used. Collected sponge pieces were transferred underwater to holding tanks with free-flowing ambient seawater and cut using a sharp scalpel into smaller pieces or explants, approximately $1 \mathrm{~cm}^{3}$ for $A$. crassa, Aplysina fistularis, Ectyoplasia ferox and Smenospongia conulosa, and $1.5 \mathrm{~cm}$ long for the 2 rope species Aplysina cauliformis and Iotrochota birotulata; explants were placed in free-flowing ambient water for $4 \mathrm{~d}$ before being used to allow them time to heal cut surfaces. Standardizing the explant size for each species prevents initial sponge size influencing growth, survival or metabolite biosynthesis (Becerro et al. 1995, Duckworth et al. 1997). Approximately 100 explants were cut for each sponge species, all with at least 1 side still covered in pinacoderm to aid survival and growth (Duckworth et al. 1997). Additional sponge biomass was frozen and used to identify the major metabolites (see 'Materials and methods-metabolite identification and characterization'). This experiment was done at the Discovery Bay Marine Laboratory, Jamaica, with natural light coming through large windows. Only A. cauliformis harbors photosynthetic symbionts (Erwin \& Thacker 2007).

\section{Experimental set-up}

Four treatments differing in water temperature $(T)$ and $\mathrm{pH}$ were tested, based on mean values at Discovery Bay, Jamaica, of approximately $28^{\circ} \mathrm{C}$ and $8.1 \mathrm{pH}$ units (Leichter \& Genovese 2006). Treatment 1 (mean $T=30.8^{\circ} \mathrm{C}$, mean $\left.\mathrm{pH}=7.78\right)$ tested predicted conditions for the year 2100 . Treatments $2\left(T=30.8^{\circ} \mathrm{C}\right.$, pH $=8.14)$ and $3\left(T=27.9^{\circ} \mathrm{C}, \mathrm{pH}=7.78\right)$ tested the individual effects of warmer water or lower $\mathrm{pH}$. Treat- ment $4\left(T=27.9^{\circ} \mathrm{C}, \mathrm{pH}=8.14\right)$ was the control using ambient conditions (for simplicity, temperature and $\mathrm{pH}$ levels are given as 28 and $31^{\circ} \mathrm{C}$, and 7.8 and 8.1, respectively, hereafter). Daily at 08:00 and 17:00 h, water temperature and $\mathrm{pH}$ in each tank were recorded using a pHep $5 \mathrm{pH} /$ temperature tester (Hanna instruments); calibrated frequently using supplied buffers, the pHep 5 compensates automatically for temperature and is accurate to $0.05 \mathrm{pH}$ units. $\mathrm{pH}$ was measured on the total scale, and like temperature, was stable over time in each treatment (1 SE = 0.01). Water samples collected for total alkalinity were lost in transit, and thus could not be analyzed. Measuring only 1 component of the carbonate system (i.e. $\mathrm{pH}$ ) meant that we could not calculate $\mathrm{pCO}_{2}$ in the experimental treatments.

Each of the 4 treatments had 3 replicate aquaria $(130 \times 50 \times 8 \mathrm{~cm})$, with each aquarium holding $52 \mathrm{l}$ of seawater. Seawater flowed through at a rate of 0.51 $\min ^{-1}$, which was sufficient to keep ammonia levels constant at $0.0 \mathrm{mg} \mathrm{l}^{-1}$, checked using ammonia test strips (Mardel). Salinity was $34 \%$. Air was pumped into each tank via 3 bubblers distributed lengthwise in the tank to provide sufficient oxygen and to mix the incoming water so temperature and $\mathrm{pH}$ were constant throughout the tank. Water temperature was raised in Treatments 1 and 2 using several $300 \mathrm{~W}$ water heaters (Aqueon) per aquarium. The $\mathrm{pH}$ was lowered in Treatments 1 and 3 by bubbling $\mathrm{CO}_{2}$ into the flow of the incoming seawater of the 6 aquaria. $\mathrm{CO}_{2}$ delivery was automated using $\mathrm{pH}$ controllers (Milwaukee SMS122) that turned on $\mathrm{CO}_{2}$ regulators (Milwaukee MA957) once the $\mathrm{pH}$ of the aquarium water exceeded 7.8. The $\mathrm{pH}$ controllers were calibrated frequently using $\mathrm{pH}$ buffers. Although we could not calculate $\mathrm{pCO}_{2}$ in each treatment, bubbling $\mathrm{CO}_{2}$ is an efficient way to manipulate carbonate chemistry of seawater and generally results in $\mathrm{pCO}_{2}$ and total alkalinity values near desired levels (Riebesell et al. 2010). Because $\mathrm{pCO}_{2}$ values were not calculated, this study focuses on the effects of seawater $\mathrm{pH}$ (and temperature) on coral reef sponges.

For each sponge species, 5 explants were grouped together and placed in each of the 12 aquaria. Species location was randomized among aquaria and each species was $>10 \mathrm{~cm}$ from neighboring species. Within a species group, explants were separated by $>3 \mathrm{~cm}$. Antagonistic interactions between and within species were unlikely because of the flow-through water system and separation among explants. It was not possible to use more aquaria to fully separate sponge species. Sponges were grown under the experimental conditions for $24 \mathrm{~d}$. 


\section{Sponge monitoring}

For all 6 sponge species, explant survival was recorded every second day, with dead explants removed immediately. Explant attachment to the aquarium floor was recorded weekly, determined by carefully touching the explant. Sponge growth was determined by comparing final explant weight to mean initial weight, the latter calculated by weighing 20 extra explants of each species that were then discarded. All explants were wet-weighed to the nearest $0.001 \mathrm{~g}$.

\section{Metabolite isolation and characterization}

The major secondary metabolites of Aiolochroia crassa, Aplysina cauliformis, Ectyoplasia ferox and Iotrochota birotulata were isolated and characterized, using the additional biomass collected. For each species, approximately $500 \mathrm{mg}$ of dry powdered sponge material was extracted with $\mathrm{MeOH}(10 \mathrm{ml}) 3$ times and vacuum dried onto $3.0 \mathrm{~g}$ Diaion ${ }^{\circledR} \mathrm{HP} 20$, a reversed phase polystyrene-divinyl benzene chromatographic resin (Van Liedekerke et al. 1989). The HP20 was placed into a column, desalted with $\mathrm{H}_{2} \mathrm{O}$ $(15 \mathrm{ml})$ and then eluted with $\mathrm{MeOH}(15 \mathrm{ml})$ and $\mathrm{Me}_{2} \mathrm{CO}(15 \mathrm{ml})$. The organic extracts were then combined and analyzed by reversed phase high performance liquid chromatography (RP-HPLC) using a photodiode array (PDA) detector and an evaporative light scattering detector (ELSD). The major metabolites were isolated by repeated preparative reversed phase HPLC (Phenomenex Gemini C18, $21 \times$ $250 \mathrm{~mm}$ ) using $\mathrm{CH}_{3} \mathrm{CN} / \mathrm{H}_{2} \mathrm{O}$ as the mobile phase. The structures of the compounds were determined by mass spectroscopy and NMR analysis $\left({ }^{1} \mathrm{H}\right.$ NMR, gCOSY, HSQC, HMBC and NOESY) ${ }^{1}$, and identified by comparison of their ${ }^{1} \mathrm{H}$ and ${ }^{13} \mathrm{C}$ NMR spectra with values in the literature.

\section{Chemical quantification}

For Aiolochroia crassa, Aplysina cauliformis, Ectyoplasia ferox and Iotrochota birotulata, chemical analysis was done using a ${ }^{1} \mathrm{H}$ NMR quantification method (Page et al. 2005) on 3 randomly chosen

${ }^{1} \mathrm{NMR}=$ nuclear magnetic resonance, $\mathrm{gCOSY}=$ gradient correlation spectroscopy, $\mathrm{HSQC}=$ heteronuclear single quantum coherence, HMBC = heteronuclear multiple bond correlation, NOESY = nuclear Overhauser effect spectroscopy explants from each aquarium; thus 9 explants were quantified per treatment. These species were chosen because their chemistry is relatively well known. To determine possible laboratory effects on metabolite biosynthesis, 3 samples of each species were collected (and quantified) from the fore reef at Discovery Bay at the end of the experiment (control samples). For each frozen explant or sample, approximately $5.0 \mathrm{~g}$ was lyophilized (48 h) to dryness and ground to a homogenous powder. Approximately $250 \mathrm{mg}$ of the dry powdered sponge material was weighed and extracted with $80 \% \mathrm{MeOH} / \mathrm{H}_{2} \mathrm{O}$ (4 ml, $10 \mathrm{~min}$ ) with stirring and filtered into a flask (20 ml) containing $2.0 \mathrm{~g}$ Diaion ${ }^{\circledR}$ HP20ss (a smaller particle size of HP20). The sponge material was reextracted twice with $\mathrm{MeOH}(4.0 \mathrm{ml}, 10 \mathrm{~min})$ and filtered into the same flask containing HP20ss. After the second $\mathrm{MeOH}$ extraction $1 \mathrm{ml}$ of $\mathrm{MeOH}$ was added through the filter into the flask. The filtrate was then concentrated onto the HP20ss. The loaded HP20ss was eluted with $\mathrm{H}_{2} \mathrm{O}(8.0 \mathrm{ml})$ and then $\mathrm{MeOH}(16 \mathrm{ml})$ into a flask $(20 \mathrm{ml})$ and concentrated to dryness under reduced pressure. For the ${ }^{1} \mathrm{H}$ NMR analysis $30 \mu \mathrm{l}(1.8 \mu \mathrm{mol})$ of a standard solution of 1,3,5-trimethoxybenzene $(50 \mathrm{mg})$ in deuterated methanol $\left(\mathrm{CD}_{3} \mathrm{OD}, 5 \mathrm{ml}\right)$ and $500 \mu \mathrm{l}$ of $\mathrm{CD}_{3} \mathrm{OD}$ were added to the dry concentrated sample. A ${ }^{1} \mathrm{H}$ NMR spectrum was obtained on a Varian Inova ${ }^{\circledR}$ spectrometer at $400 \mathrm{MHz}$ with the following acquisition and processing parameters: $T=16.7^{\circ} \mathrm{C} / 290 \mathrm{~K}$, relaxation delay $15.0 \mathrm{~s}$, pulse width $90.0^{\circ}$, acquisition time $5.0 \mathrm{~s}, 32$ repetitions, line broadening $0.5 \mathrm{~Hz}$, total time $11 \mathrm{~min}, 31 \mathrm{~s}$. The integrals of proton resonances at $\delta 1.85(\mathrm{qt}, 2 \mathrm{H}), 2.55(\mathrm{t}, 2 \mathrm{H}), 2.70(\mathrm{t}, 2 \mathrm{H})$, $2.91(\mathrm{~s}, 2 \mathrm{H}), 3.15(\mathrm{~s}, 3 \mathrm{H}), 3.65(\mathrm{t}, 2 \mathrm{H}), 6.42(\mathrm{~s}, 1 \mathrm{H})$, $6.51(\mathrm{~s}, 1 \mathrm{H})$ and $6.53(\mathrm{~s}, 1 \mathrm{H})$ for A. crassa; $\delta 2.93(\mathrm{~s}$, $3 \mathrm{H}), 3.51(\mathrm{t}, 2 \mathrm{H}), 3.63(\mathrm{t}, 2 \mathrm{H}), 3.73(\mathrm{~s}, 6 \mathrm{H}), 6.43(\mathrm{~d}$, $2 \mathrm{H})$ and $7.62(\mathrm{~s}, 2 \mathrm{H})$ for A. cauliformis; $\delta 3.81(\mathrm{~s}, 3 \mathrm{H})$, $3.87(\mathrm{~s}, 3 \mathrm{H}), 4.50(\mathrm{~s}, 2 \mathrm{H}), 7.40(\mathrm{~s}, 1 \mathrm{H}), 8.17(\mathrm{t}, 1 \mathrm{H})$, $8.83(\mathrm{~s}, 1 \mathrm{H}), 8.95(\mathrm{dd}, 2 \mathrm{H})$ and $9.24(\mathrm{~s}, 1 \mathrm{H})$ for $E$. ferox; and $\delta 2.55(\mathrm{t}, 2 \mathrm{H}), 2.74(\mathrm{~s}, 2 \mathrm{H}), 7.37(\mathrm{~s}, 1 \mathrm{H})$ and $8.53(\mathrm{~s}, 1 \mathrm{H})$ for $I$. birotulata were compared to the integral of the standard 1,3,5-trimethoxybenzene resonance at $\delta 6.10$ to determine the molar quantities of the analytes. For each sponge species, 1 to 3 major secondary metabolites were quantified with concentrations given in mg per g dry weight of sponge (hereafter: $\mathrm{mg} \mathrm{g}^{-1}$ sponge). Although the ecological role is known for only some of the secondary metabolites, all examined metabolites provide information about the possible effects of environmental stress caused by warmer, more acidic water. 


\section{Data analysis}

For each sponge species, final weight, survival, attachment and metabolite concentration(s) were statistically analyzed using 2-way ANOVAs, with temperature and $\mathrm{pH}$ as fixed factors. Mean values per aquarium of each sponge measurement (e.g. final weight) were used to avoid pseudoreplication, so each treatment had 3 replicates. Survival was only analyzed for species with dead explants. When necessary, data was log-transformed to meet assumptions of ANOVA, and Tukey-Kramer multiple comparison tests were used to determine which treatments differed significantly.

\section{RESULTS}

\section{Growth}

For each sponge species, growth was unaffected by water temperature or $\mathrm{pH}$ and there was no significant interaction term (Table 1). Growth varied greatly among the 6 sponge species (Fig. 1), being highest (as a percentage of initial weight) after $4 \mathrm{wk}$ for Aplysina cauliformis (0.5 g or $42.1 \%$ increase), followed by Aiolochroia crassa $(0.9 \mathrm{~g}, 39.4 \%)$, Iotrochota birotulata $(0.5 \mathrm{~g}, 31.5 \%)$, Smenospongia conulosa (0.9 g, $28.9 \%)$, Aplysina fistularis $(0.5 \mathrm{~g}, 20.1 \%$ ) and lastly

Table 1. Summary of 2-way ANOVAs testing effects of water temperature and $\mathrm{pH}$ on growth, survival and attachment of 6 species of coral reef sponge. F-ratios shown under each factor and interaction. Probability: $\mathrm{ns}=$ not significant; ${ }^{*} \mathrm{p}<$ $0.05_{i}{ }^{* *} \mathrm{p}<0.01 ; \mathrm{df}=1,8$ for all analyses. Survival and attachment analyses not shown for species where all sponges survived or attached by end of experiment. Species: Aiolochroia crassa, Aplysina cauliformis, Aplysina fistularis, Ectyoplasia ferox, Iotrochota birotulata, Smenospongia conulosa

\begin{tabular}{|lcccc|}
\hline Species & Measurement & Temp. & $\mathrm{pH}$ & $\begin{array}{c}\text { Temp. } \times \\
\mathrm{pH}\end{array}$ \\
\hline A. crassa & Growth & $0.52^{\mathrm{ns}}$ & $0.01^{\mathrm{ns}}$ & $0.03^{\mathrm{ns}}$ \\
& Survival & $0.64^{\mathrm{ns}}$ & $0.07^{\mathrm{ns}}$ & $0.64^{\mathrm{ns}}$ \\
A. cauliformis & Growth & $2.23^{\mathrm{ns}}$ & $0.31^{\mathrm{ns}}$ & $0.34^{\mathrm{ns}}$ \\
A. fistularis & Growth & $1.52^{\mathrm{ns}}$ & $0.00^{\mathrm{ns}}$ & $0.05^{\mathrm{ns}}$ \\
E. ferox & Growth & $0.57^{\mathrm{ns}}$ & $0.59^{\mathrm{ns}}$ & $3.23^{\mathrm{ns}}$ \\
& Attachment & $16.00^{* *}$ & $4.00^{\mathrm{ns}}$ & $4.00^{\mathrm{ns}}$ \\
I. birotulata & Growth & $0.98^{\mathrm{ns}}$ & $0.35^{\mathrm{ns}}$ & $0.14^{\mathrm{ns}}$ \\
& Attachment & $7.00^{*}$ & $0.14^{\mathrm{ns}}$ & $0.14^{\mathrm{ns}}$ \\
S. conulosa & Growth & $4.92^{\mathrm{ns}}$ & $2.92^{\mathrm{ns}}$ & $0.00^{\mathrm{ns}}$ \\
& Survival & $0.08^{\mathrm{ns}}$ & $2.08^{\mathrm{ns}}$ & $0.75^{\mathrm{ns}}$ \\
& Attachment & $0.70^{\mathrm{ns}}$ & $0.00^{\mathrm{ns}}$ & $2.56^{\mathrm{ns}}$ \\
\hline
\end{tabular}
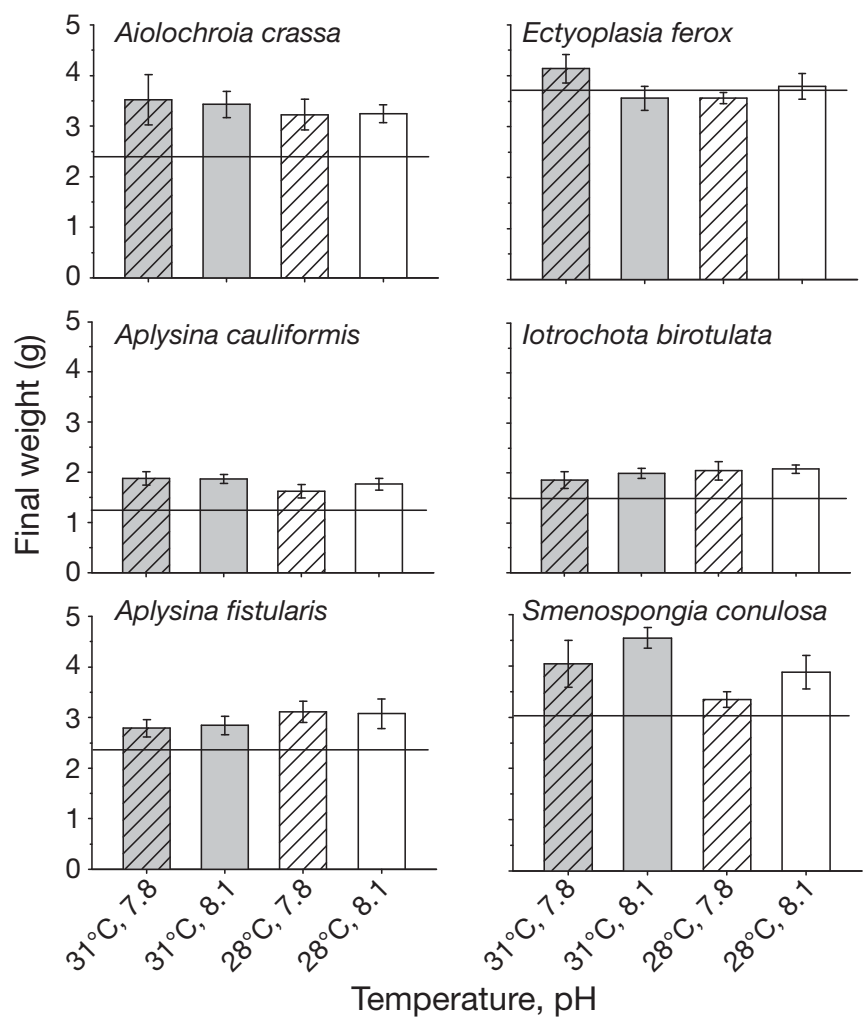

Temperature, $\mathrm{pH}$

Fig. 1. Mean \pm SE weights of 6 species of coral reef sponge grown under differing levels of water temperature and $\mathrm{pH}$. The horizontal line on each graph represents the mean initial weight

Ectyoplasia ferox $(<0.1 \mathrm{~g}, 0.1 \%)$. For all species, variation in growth was generally low within treatments, being about $\pm 10 \%$ of mean final weight.

\section{Survival}

All explants of Aplysina cauliformis, Aplysina fistularis, Ectyoplasia ferox and Iotrochota birotulata survived regardless of treatment. Final explant survival for Aiolochroia crassa and Smenospongia conulosa was similar among temperature and $\mathrm{pH}$ levels (Table 1), averaging $78 \%$ and $82 \%$ respectively. The dead sponges were covered in a grayish microbial film, which did not infect neighboring explants. The necrotic sponges typically died within $1 \mathrm{~d}$ of first observation of the microbial film. For both species, most explants died during the first $10 \mathrm{~d}$ of the experiment.

\section{Attachment}

Rates of attachment varied greatly among the 6 sponge species; fastest for Aplysina fistularis where 
all sponges had attached within $7 \mathrm{~d}$, and slowest for Ectyoplasia ferox where $<15 \%$ of explants had attached by Day 24 (Fig. 2). For E. ferox and Iotrochota birotulata, final sponge attachment varied significantly between temperatures (Table 1), and was fastest at $31^{\circ} \mathrm{C}$ (Fig. 2). Aplysina cauliformis also attached fastest at $31^{\circ} \mathrm{C}$ (Fig. 2). In contrast, sponge attachment was similar between temperature levels for Aiolochroia crassa, Aplysina fistularis and Smenospongia conulosa (Table 1, Fig. 2). Even though an artificial substrate was used, the fast attachment rates for some species suggest that it did not interfere with the attachment process.

\section{Secondary metabolites}

The concentrations of 3 metabolites were analyzed from Aiolochroia crassa, with 2 identified: $N, N^{\prime}$-dimethylhistamine and $N$-methyl-aerophobin 2 ; the third metabolite (hereafter Metabolite 1) was unable to be identified. For all 3 metabolites, final concentrations were similar among temperature and $\mathrm{pH}$ levels, and there was no significant interaction term (Table 2). Concentrations of $N, N^{\prime}$-dimethylhistamine were similar between laboratory sponges and wild conspecifics, while concentrations of $\mathrm{N}$ methyl-aerophobin 2 and Metabolite 1 were lower in laboratory sponges (Fig. 3). Concentrations varied greatly among metabolites. For example, the mean concentration of $N$-methyl-aerophobin 2 (8.3 $\mathrm{mg} \mathrm{g}^{-1}$ sponge) was almost 4 times higher than $N, N^{\prime}$-dimethylhistamine $\left(2.1 \mathrm{mg} \mathrm{g}^{-1}\right.$ sponge). Metabolite 1 concentration averaged $5.9 \mathrm{mg} \mathrm{g}^{-1}$ sponge.

The concentrations of 2 metabolites were analyzed for Aplysina cauliformis: fistularin 3 was identified and the second, hereafter Metabolite 2, was not identified. Final metabolite concentrations were not significantly affected by water temperature and $\mathrm{pH}$ (Table 2, Fig. 4), averaging 13.0 and $3.7 \mathrm{mg} \mathrm{g}^{-1}$ sponge for fistularin 3 and Metabolite 2, respectively. Metabolite concentrations in laboratory sponges were similar to those found in

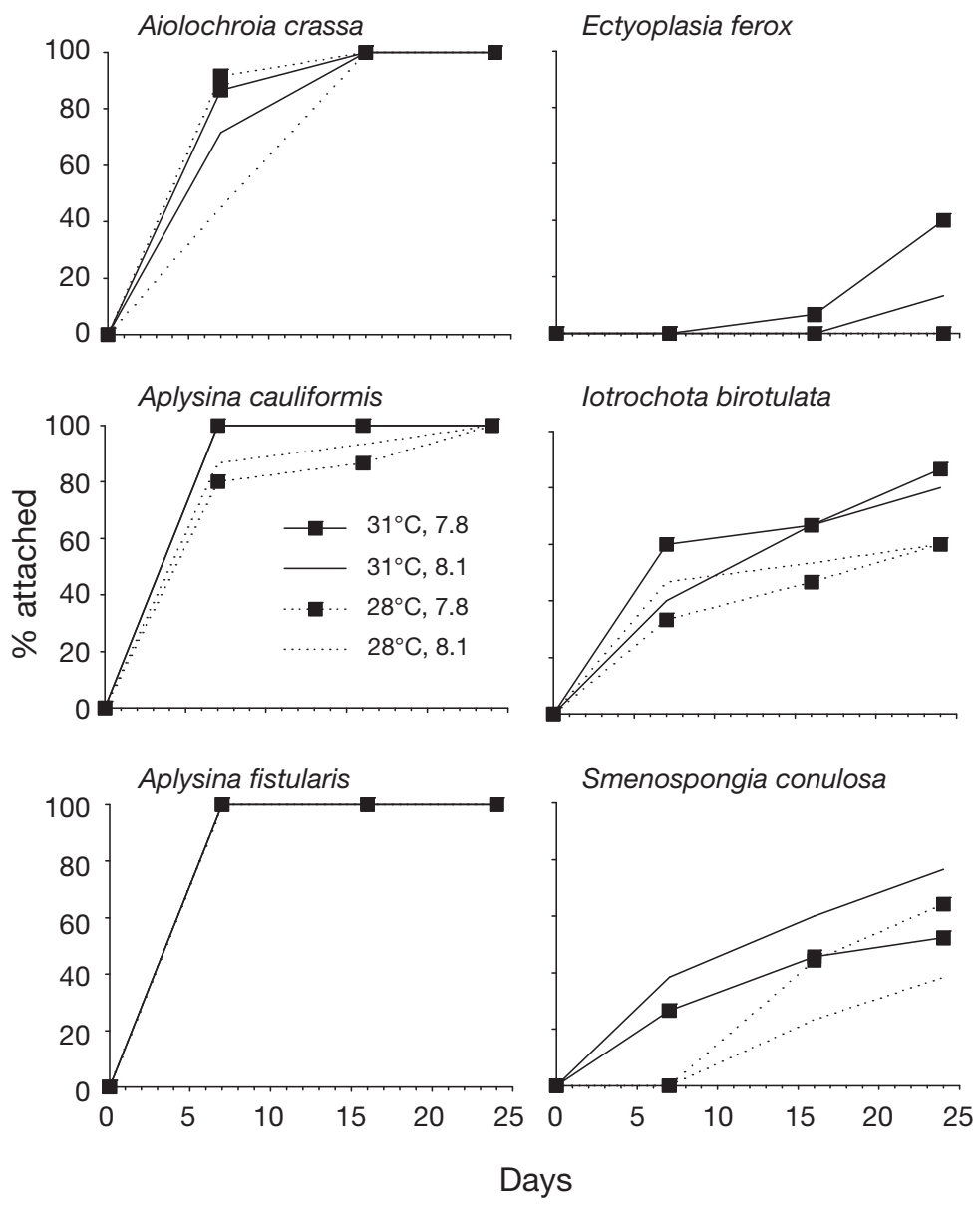

Fig. 2. Mean sponge attachment over time of 6 species of coral reef sponge grown under differing levels of water temperature and $\mathrm{pH}$

Table 2. Summary of 2-way ANOVAs testing effects of water temperature and $\mathrm{pH}$ on metabolite concentrations in 4 species of coral reef sponge. $F$ ratios shown under each factor and interaction. Probability: ns = not significant $^{*} \mathrm{p}<0.05$; $\mathrm{df}=1,8$ for all metabolites. See Table 1 for full species names

\begin{tabular}{|c|c|c|c|c|}
\hline Species & Metabolite & Temp. & $\mathrm{pH}$ & $\begin{array}{c}\text { Temp. } \times \\
\text { pH }\end{array}$ \\
\hline A. crassa & $\begin{array}{l}N, N^{\prime} \text {-dimethylhistamine } \\
N \text {-methyl-aerophobin } 2 \\
\text { Metabolite } 1\end{array}$ & $\begin{array}{l}0.98^{\mathrm{ns}} \\
2.85^{\mathrm{ns}} \\
2.42^{\mathrm{ns}}\end{array}$ & $\begin{array}{l}0.82^{\text {ns }} \\
0.01^{\text {ns }} \\
1.10^{\text {ns }}\end{array}$ & $\begin{array}{l}0.65^{\mathrm{ns}} \\
0.21^{\mathrm{ns}} \\
0.99^{\mathrm{ns}}\end{array}$ \\
\hline A. cauliformis & $\begin{array}{l}\text { Fistularin } 3 \\
\text { Metabolite } 2\end{array}$ & $\begin{array}{l}3.33^{\text {ns }} \\
3.62^{\text {ns }}\end{array}$ & $\begin{array}{l}0.32^{\text {ns }} \\
2.82^{\text {ns }}\end{array}$ & $\begin{array}{l}0.88^{\text {ns }} \\
0.02^{\text {ns }}\end{array}$ \\
\hline E. ferox & $\begin{array}{l}\text { Zooanemonin } \\
\text { Metabolite } 3\end{array}$ & $\begin{array}{l}11.08^{*} \\
0.07^{\text {ns }}\end{array}$ & $\begin{array}{l}0.21^{\mathrm{ns}} \\
0.84^{\mathrm{ns}}\end{array}$ & $\begin{array}{l}2.27^{\mathrm{ns}} \\
0.66^{\mathrm{ns}}\end{array}$ \\
\hline I. birotulata & $N$-tele-methylhistamine & $0.05^{\mathrm{ns}}$ & $3.62^{\text {ns }}$ & $8.46^{*}$ \\
\hline
\end{tabular}

wild conspecifics (Fig. 4). For Metabolite 2, concentrations varied greatly among wild but not laboratory A. cauliformis. 


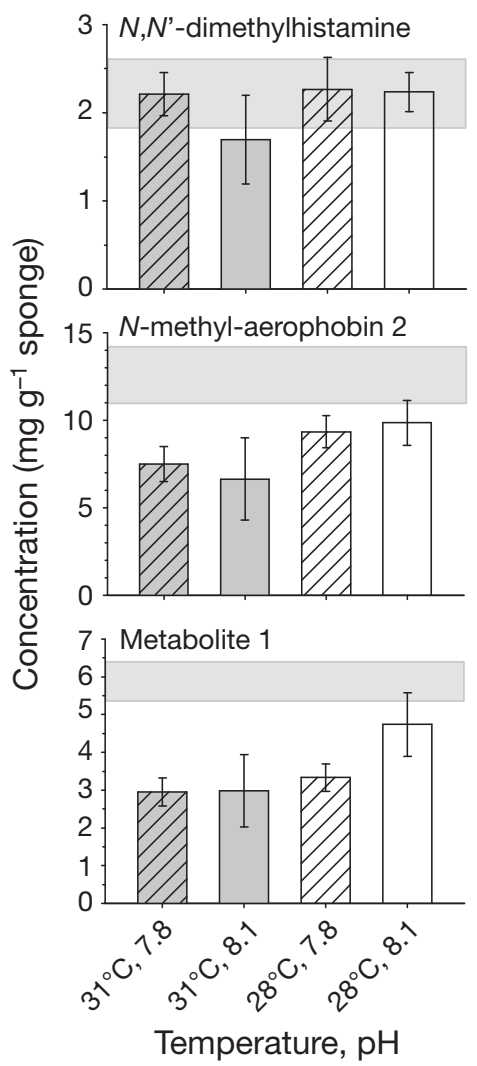

Fig. 3. Aiolochroia crassa. Mean \pm SE concentrations of 3 metabolites biosynthesized under differing levels of water temperature and $\mathrm{pH}$. The grey horizontal bars show the range in metabolite concentration from 3 wild conspecifics

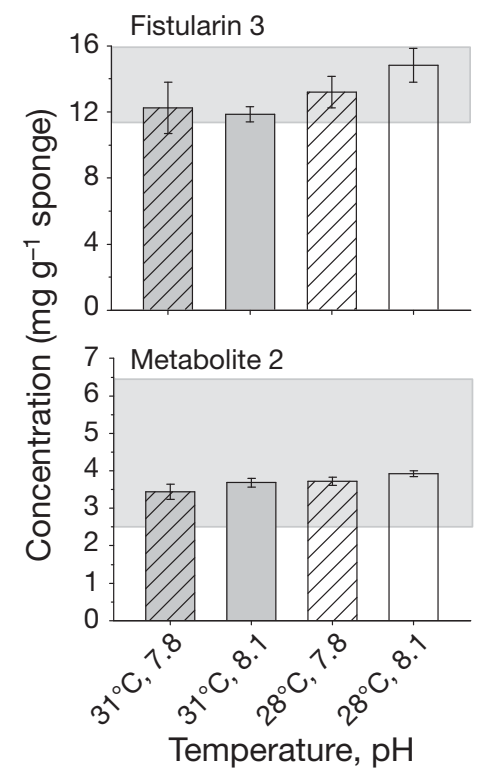

Fig. 4. Aplysina cauliformis. Mean \pm SE concentrations of 2 metabolites biosynthesized under differing levels of water temperature and $\mathrm{pH}$. The grey horizontal bars show the range in metabolite concentration from 3 wild conspecifics

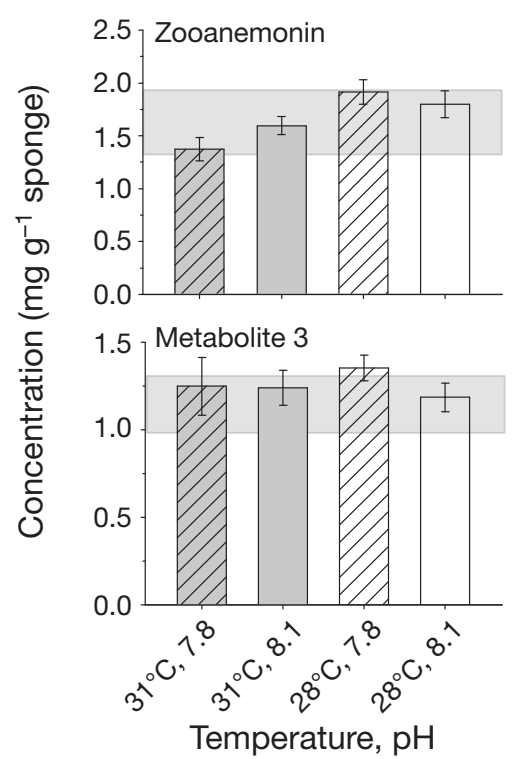

Fig. 5. Ectyoplasia ferox. Mean \pm SE concentrations of 2 metabolites biosynthesized under differing levels of water temperature and $\mathrm{pH}$. The grey horizontal bars show the range in metabolite concentration from 3 wild conspecifics

The concentrations of 2 metabolites were analyzed for Ectyoplasia ferox: zooanemonin and an unidentified second metabolite (hereafter Metabolite 3). Zooanemonin concentration varied significantly between temperatures (Table 2), and was $20 \%$ higher in sponges grown at $28^{\circ} \mathrm{C}$ (Fig. 5), with a mean concentration of $1.9 \mathrm{mg} \mathrm{g}^{-1}$ sponge compared to $1.5 \mathrm{mg}$ $\mathrm{g}^{-1}$ sponge for explants grown at $31^{\circ} \mathrm{C}$. Concentrations of Metabolite 3 did not vary significantly among treatments (Table 2), averaging $1.3 \mathrm{mg} \mathrm{g}^{-1}$ sponge. For both metabolites, concentrations in laboratory sponges mostly fell within the range found in 3 wild sponges (Fig. 5).

For Iotrochota birotulata, concentrations of the metabolite $\mathrm{N}$-tele-methylhistamine varied significantly among treatments (Table 2). The TukeyKramer multiple comparison test determined that metabolite concentration differed only between I. birotulata grown at $28^{\circ} \mathrm{C}$ and $\mathrm{pH}=8.1$ (mean $=$ $2.9 \mathrm{mg} \mathrm{g}^{-1}$ sponge) and sponges at $28^{\circ} \mathrm{C}$ and $\mathrm{pH}=7.8$ (2.2 $\mathrm{mg} \mathrm{g} \mathrm{sponge}^{-1}$ ) (Fig. 6). However, mean concentrations of $N$-tele-methylhistamine in all 4 treatments fell within or close to the range found in 3 wild I. birotulata (Fig. 6).

\section{DISCUSSION}

Final sponge size and survival for each species were similar between current and predicted values (year 


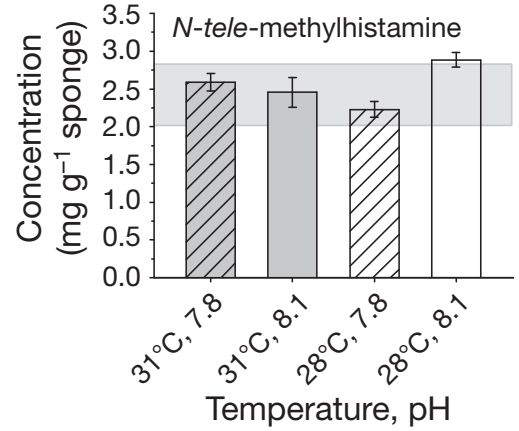

Fig. 6. Iotrochota birotulata. Mean \pm SE concentrations of $N$ tele-methylhistamine biosynthesized under differing levels of water temperature and $\mathrm{pH}$. The grey horizontal bar shows the range in metabolite concentration from 3 wild conspecifics

2100) of water temperature and $\mathrm{pH}$ for Jamaican coral reefs. Growth and survival may have been unaffected by higher water temperature because the studied species occur in habitats and/or depths that episodically experience high temperatures. In Jamaica, Aplysina fistularis, Ectyoplasia ferox and Iotrochota birotulata have been recorded from depths of $<3 \mathrm{~m}$ in lagoons and harbors (Hechtel 1965, Lehnert \& Van Soest 1998) where water temperatures reach $31^{\circ} \mathrm{C}$ (Wade 1972). These 3 species plus Aiolochroia crassa and Aplysina cauliformis are also found between 1 and $5 \mathrm{~m}$ deep on coral reefs throughout the Caribbean region (e.g. Schmahl 1990, Sullivan \& Chiappone 1992, Zea 2001, Diaz 2005). At these shallow depths, water temperature can exceed $31^{\circ} \mathrm{C}$ on summer days and stay above $30^{\circ} \mathrm{C}$ for several weeks (Kaufmann \& Thompson 2005). Depth patterns are poorly documented for Smenospongia conulosa, but in Jamaica it is common at depths of 8 to $10 \mathrm{~m}$ (A. Stubler unpubl. data) where water temperature can exceed $30^{\circ} \mathrm{C}$ during summer (Leichter \& Genovese 2006). Perhaps, if the sponge species were grown at elevated temperatures for $>24 \mathrm{~d}$, which was the duration of this experiment, significant differences between temperature regimes may have resulted. Overall, the lack of relationship (within $24 \mathrm{~d}$ ) between water temperature and sponge growth agrees with findings for some other coral reef sponge species (e.g. Hoppe 1988, Duckworth \& Wolff 2011) though not all (e.g. Reiswig 1973, McMurray et al. 2008).

Although the studied sponges can survive and grow in waters at $31^{\circ} \mathrm{C}$ in aquaria or in the field, this does not necessarily indicate that future temperature increases will have no effect on sponge survival. Water temperature at shallow depths can rise $>2^{\circ} \mathrm{C}$ above mean values for short periods during summer
(Kaufmann \& Thompson 2005). This corresponds to a predicted temperature of $33^{\circ} \mathrm{C}$, a level that can rapidly break down the symbiotic relationship between a coral reef sponge and its microbes, causing necrosis (Webster et al. 2008). Microbes, for example, play an essential role in energy transfer for Aiolochroia crassa, Aplysina cauliformis, Aplysina fistularis and Ectyoplasia ferox (Weisz et al. 2008). High water temperatures can also increase the severity of disease outbreaks which can devastate sponge populations (Ayling 1981, Maldonado et al. 2010).

In contrast to growth and survival, high water temperature did promote the rate of sponge attachment for Aplysina cauliformis, Ectyoplasia ferox and Iotrochota birotulata. The fast attachment rate for Aplysina fistularis ( $<7$ d) likely obscured any differences between temperature levels. Positive relationships between temperature and sponge attachment rates have been found previously (Barthel \& Theede 1986, Rosell \& Uriz 1992) and may result from warmer water promoting secretion of the basal lamella by basopinacocytes. Attachment of sponge fragments to loose rubble helps consolidate coral reefs (Wulff 1984), so future temperature increases may promote this process to some degree. Faster attachment rates may also result in fewer sponge fragments being lost off the reef. Attachment rates varied greatly among the 6 coral reef species; this may result in part from their general morphology. Fragments of branching (e.g. A. cauliformis) and tubular coral reef sponges (e.g. A. fistularis) are generally more successful in reattaching than massive species (e.g. Smenospongia conulosa) (Wulff 2006). The one exception to this general relationship was the massive sponge Aiolochroia crassa that quickly attached, probably because explants were cut using a sharp scalpel and so experienced less internal damage than being macerated by storm damage as witnessed in Wulff's (2006) study.

Seawater $\mathrm{pH}$ did not influence sponge attachment for any of the 6 species, although a similar study found that fewer explants of the temperate sponge Cliona celata attached to scallop shells at $\mathrm{pH}=7.8$ than at $\mathrm{pH}=8.1$ (A. R. Duckworth unpubl. data). That study also found that survival of C. celata was lower at $\mathrm{pH}=7.8$. Cliona spp. are boring sponges, however, that preferentially settle in a carbonate rich environment (Rosell \& Uriz 1992), so effects of low pH on C. celata likely differ from the non-boring sponges examined here. Previous studies suggest that the response of sponges to changing $\mathrm{pH}$ levels will vary among species and could have negative impact on their distributions (Jewell 1939, Southward et al. 
1996). Perhaps seawater $\mathrm{pH}$ of 7.8 had little effect on growth, survival and attachment of the studied sponges because all may be considered 'generalist' species, found in differing habitats and able to live in a variety of environmental conditions. Coral reef sponges may also be less susceptible to low $\mathrm{pH}$ than other reef invertebrates because of their simpler organization. Low pH, for example, can kill or damage corals and sea urchins by causing high levels of carbonic acid in bodily fluids (e.g. blood) and tissues (Fabry et al. 2008, Przeslawski et al. 2008), which sponges do not have.

Although water temperature and $\mathrm{pH}$ had little influence on sponge growth and survival, both responses varied greatly among the 6 coral reef species. The 2 species that experienced some mortality-Aiolochroia crassa and Smenospongia conulosa - have a massive morphology, and thus required greater cutting of donor sponges to generate explants, which leads to higher levels of initial damage. This likely explains why most sponge deaths occurred during the first $10 \mathrm{~d}$ of the study, while they were still repairing their aquiferous systems. Large differences in growth rates (ranging from 0.1 to $42.1 \%$ ) are common among coral reef species (Reiswig 1973, Hoppe 1988, Leong \& Pawlik 2010, Duckworth \& Wolff 2011) and may result from interspecific differences in food retention and skeletal structure (Reiswig 1971, Duckworth \& Battershill 2003, Duckworth et al. 2006). Growth rates recorded here are comparable to wild conspecifics (Wilkinson \& Cheshire 1988, Wulff 1991, Leong \& Pawlik 2010), indicating that the sponges (except possibly Ectyoplasia ferox) were receiving sufficient food.

Of the 9 secondary metabolites examined in this study, only concentrations of zooanemonin from Ectyoplasia ferox and N-tele-methylhistamine from Iotrochota birotulata varied significantly among treatments. Zooanemonin killed barnacles in a laboratory study at a concentration of $0.05 \mathrm{mg} \mathrm{g}^{-1}$ wet sponge (Hattori et al. 2001); using wet-to-dry-weight conversions for sponges (Ricciardi \& Bourget 1998) this corresponds to an estimated value of $0.3 \mathrm{mg} \mathrm{g}^{-1}$ sponge. In this study, final concentrations of zooanemonin in E. ferox varied significantly between temperatures, and were 1.9 and $1.5 \mathrm{mg} \mathrm{g}^{-1}$ sponge at 28 and $31^{\circ} \mathrm{C}$, respectively. Although $20 \%$ higher at the lower temperature, both concentrations are well above the lethal level for barnacles. In addition, mean zooanemonin concentrations at both temperatures fell within the range shown by wild E. ferox. These results suggest that zooanemonin concentration in E. ferox would still be sufficiently high to pre- vent fouling at temperature levels predicted for 2100 . For N-tele-methylhistamine, mean concentration was almost $25 \%$ higher for $I$. birotulata grown at $28^{\circ} \mathrm{C}$ and $\mathrm{pH}=8.2$ than at $28^{\circ} \mathrm{C}$ and $\mathrm{pH}=7.8$. Although seawater $\mathrm{pH}$ influenced metabolite biosynthesis at $28^{\circ} \mathrm{C}$, it had little effect at the temperature predicted by the end of this century. In addition, mean metabolite concentrations in all 4 treatments fell within or near the range found in 3 wild sponges. Again this suggests that predicted values of $\mathrm{pH}$ and temperature will likely have little effect on $N$-telemethylhistamine biosynthesis and its ecological role in I. birotulata.

The secondary metabolites isolated here are only some of metabolites biosynthesized in each species. Aiolochroia crassa and Aplysina cauliformis, for example, each have had 15 metabolites identified (Ciminiello et al. 1995, Ciminiello et al. 1999) while only the major 3 and 2 metabolites, respectively, were examined in this study. Secondary metabolites may also be rapidly biosynthesized in response to unpredictable events or triggers like predator damage (Thoms et al. 2006). Effects of seawater $\mathrm{pH}$ and temperature on this 'activated chemical defense' is only possible in presence of the 'trigger', which was not feasible to do in this study. Final concentrations of 2 metabolites in A. crassa were lower in laboratory sponges than wild conspecifics, indicating that growing sponges in aquaria can influence the biosynthesis of some metabolites. Lower metabolite concentrations were probably not a damage response from being cut into explants (i.e. activated chemical defense) because sponge samples were collected and frozen $24 \mathrm{~d}$ after cutting. These limitations mean that a complete analysis of the effects of warmer, more acidic waters on all secondary metabolites from each sponge species is not possible. Considering the major secondary metabolites only, this study suggests that the ecological functions or roles of these metabolites will likely be little affected, if at all, by values of water temperature and $\mathrm{pH}$ predicted for 2100.

Levels of water temperature and $\mathrm{pH}$ tested in this study had little effect on sponge growth, survival and major metabolite concentrations (when considering natural variation), with only attachment rates of some species faster at the higher temperature. Effects of warmer, more acidic water on marine invertebrates can vary among life stages (Kurihara 2008), so responses of larvae or juvenile individuals of the studied species could differ from the results shown here by adult sponges. If, however, predicted values of water temperature and $\mathrm{pH}$ have little impact on all life stages of coral reef sponges, while negatively 
affecting growth and survival of corals (Hoegh-Guldberg et al. 2007), it is likely that sponges would become more important in providing ecological services such as creating habitat on coral reefs in the Caribbean.

Acknowledgements. This study was funded by the Disney Worldwide Conservation Fund, Blue Ocean Institute and Florida Atlantic University. We thank the Discovery Bay Marine Laboratory for their help during the field work, and the anonymous referees for their comments.

\section{LITERATURE CITED}

Abdo DA, Motti CA, Battershill CN, Harvey ES (2007) Temperature and spatiotemporal variability of salicylihalamide $\mathrm{A}$ in the sponge Haliclona sp. J Chem Ecol 33: 1635-1645

Aerts LAM (1998) Sponge/coral interactions in Caribbean reefs: analysis of overgrowth patterns in relation to species identity and cover. Mar Ecol Prog Ser 175:241-249

Anthony KRN, Kline DI, Diaz-Pulldo G, Dove S, HoeghGuldberg O (2008) Ocean acidification causes bleaching and productivity loss in coral reef builders. Proc Natl Acad Sci USA 105:17442-17446

Ayling AM (1981) The role of biological disturbance in temperate subtidal encrusting communities. Ecology 62: 830-847

Barthel D, Theede H (1986) A new method for the culture of marine sponges and its application for experimental studies. Ophelia 25:75-82

Becerro MA, Turon X, Uriz MJ (1995) Natural variation of toxicity in encrusting sponge Crambe crambe (Schmidt) in relation to size and environment. J Chem Ecol 21: 1931-1946

Butler M, Herrnkind W, Hunt J (1994) Sponge mass mortality and Hurricane Andrew: catastrophe for juvenile spiny lobsters in south Florida? Bull Mar Sci 54:1073

Ciminiello P, Fattorusso E, Magno S (1995) Chemistry of Verongida sponges, IV. Comparison of the secondary metabolite composition of several specimens of Pseudoceratina crassa. J Nat Prod 58:689-696

> Ciminiello P, Dell'Aversano C, Fattorusso E, Magno S, Pansini M (1999) Chemistry of Verongida sponges. 9. Secondary metabolite composition of the Caribbean sponge Aplysina cauliformis. J Nat Prod 62:590-593

Diaz MC (2005) Common sponges from shallow marine habitats from Bocas del Toro region, Panama. Caribb J Sci 41:465-475

Diaz MC, Rützler K (2001) Sponges: an essential component of Caribbean coral reefs. Bull Mar Sci 69:535-546

> Diers JA, Kishore Pennaka H, Peng J, Bowling JJ, Duke SO, Hamann MT (2004) Structural activity relationship studies of zebra mussel antifouling and antimicrobial agents from Verongid sponges. J Nat Prod 67:2117-2120

> Duckworth AR (2003) Effect of wound size on the growth and regeneration of two temperate subtidal sponges. J Exp Mar Biol Ecol 287:139-153

Duckworth AR, Battershill CN (2003) Sponge aquaculture for the production of biologically active metabolites: the influence of farming protocols and the environment. Aquaculture 221:311-329
Duckworth AR, Wolff CW (2011) Population dynamics and growth of two coral reef sponges on rock and rubble substrates. J Exp Mar Biol Ecol 402:49-55

> Duckworth AR, Battershill CN, Bergquist PR (1997) Influence of explant procedures and environmental factors on culture success of three sponges. Aquaculture 156:251-267

> Duckworth AR, Brück WM, Janda KE, Pitts TP, McCarthy PJ (2006) Retention efficiencies of the coral reef sponges Aplysina lacunosa, Callyspongia vaginalis and Niphates digitalis determined by Coulter counter and plate culture analysis. Mar Biol Res 2:243-248

> Engel S, Pawlik JR (2000) Alleopathic activities of sponge extracts. Mar Ecol Prog Ser 207:273-281

- Erwin PM, Thacker RW (2007) Incidence and identity of photosynthetic symbionts in Caribbean coral reef sponge assemblages. J Mar Biol Assoc UK 87:1683-1692

$>$ Fabry VJ, Seibel BA, Feely RA, Orr JC (2008) Impacts of ocean acidification on marine fauna and ecosystem processes. ICES J Mar Sci 65:414-432

> Guinotte JM, Fabry VJ (2008) Ocean acidification and its potential effects on marine ecosystems. Ann N Y Acad Sci 1134:320-342

> Hattori T, Matsuo S, Adachi K (2001) Isolation of antifouling substances from the Palauan sponge Protophlitaspongia aga. Fish Sci 67:690-693

Hechtel GJ (1965) A systematic study of the Demospongiae of Port Royal, Jamaica. Bull Peabody Mus Nat His 20: $1-103$

Hoegh-Guldberg O, Mumby PJ, Hooten AJ, Steneck RS and others (2007) Coral reefs under rapid climate change and ocean acidification. Science 318:1737-1742

Hoppe WF (1988) Growth, regeneration and predation in three species of large coral reef sponges. Mar Ecol Prog Ser 50:117-125

Jewell ME (1939) An ecological study of the fresh-water sponges of Wisconsin, II. The influence of calcium. Ecology 20:11-28

Kaufmann KW, Thompson RC (2005) Water temperature variation and the meteorological and hydrographic environment of Bocas del Toro, Panama. Caribb J Sci 41: 392-413

Kelly SR, Jensen PR, Henkel TP, Fenical W, Pawlik JR (2003) Effects of Caribbean sponge extracts on bacterial attachment. Aquat Microb Ecol 31:175-182

> Kiessling W, Simpson C (2011) On the potential for ocean acidification to be a general cause of ancient reef crises. Glob Change Biol 17:56-67

Kurihara $\mathrm{H}$ (2008) Effects of $\mathrm{CO}_{2}$-driven ocean acidification on the early developmental stages of invertebrates. Mar Ecol Prog Ser 373:275-284

Lehnert H, Van Soest RWM (1998) Shallow water sponges of Jamaica. Beaufortia 48:71-103

Leichter JJ, Genovese SJ (2006) Intermittent upwelling and subsidized growth of the scleractinian coral Madracis mirabilis on the deep fore-reef slope of Discovery Bay, Jamaica. Mar Ecol Prog Ser 316:95-103

León YM, Bjorndal KA (2002) Selective feeding in the hawksbill turtle, an important predator in coral reef ecosystems. Mar Ecol Prog Ser 245:249-258

> Leong W, Pawlik JR (2010) Evidence of a resource trade-off between growth and chemical defenses among Caribbean coral reef sponges. Mar Ecol Prog Ser 406:71-78

Lesser MP (2006) Benthic-pelagic coupling on coral reefs: feeding and growth of Caribbean sponges. J Exp Mar Biol Ecol 328:277-288 
Lindel T, Hoffmann H, Hochgütel M, Pawlik JR (2000) Structure-activity relationship of inhibition of fish feeding by sponge-derived and synthetic pyrrole-imidazole alkaloids. J Chem Ecol 26:1477-1496

López-Victoria M, Zea S, Weil E (2006) Competition for space between encrusting excavating Caribbean sponges and other coral reef organisms. Mar Ecol Prog Ser 312:113-121

Maldonado M, Sánchez-Tocino L, Navarro C (2010) Recurrent disease outbreaks in corneous demosponges of the genus Ircinia: epidemic incidence and defense mechanisms. Mar Biol 157:1577-1590

McMurray SE, Blum JE, Pawlik JR (2008) Redwood of the reef: growth and age of the giant barrel sponge Xestospongia muta in the Florida Keys. Mar Biol 155: 159-171

Munday PL, Crawley NE, Nilsson GE (2009) Interacting effects of elevated temperature and ocean acidification on the aerobic performance of coral reef fishes. Mar Ecol Prog Ser 388:235-242

> Orr JC, Fabry VJ, Aumont O, Bopp L and others (2005) Anthropogenic ocean acidification over the twenty-first century and its impact on calcifying organisms. Nature 437:681-686

Page M, West L, Northcote PT, Battershill CN, Kelly M (2005) Spatial and temporal variability of cytotoxic metabolites in populations of the New Zealand sponge Mycale hentscheli. J Chem Ecol 31:1161-1174

Pawlik JR (1993) Marine invertebrate chemical defense. Chem Rev 93:1911-1922

Pawlik JR, Chanas B, Toonen RJ, Fenical W (1995) Defenses of Caribbean sponges against predatory reef fish. I. Chemical deterrency. Mar Ecol Prog Ser 127:183-194

Pawlik JR, McMurray SE, Henkel TP (2007) Abiotic factors control sponge ecology in Florida mangroves. Mar Ecol Prog Ser 339:93-98

Porter JW, Targett NM (1988) Allelochemical interactions between sponges and corals. Biol Bull 175:230-239

Przeslawski R, Ahyong S, Byrne M, Wörheide G, Hutchings PAT (2008) Beyond corals and fish: the effects of climate change on noncoral benthic invertebrates of tropical reefs. Glob Change Biol 14:2773-2795

Randall JE, Hartman WD (1968) Sponge-feeding fishes of the West Indies. Mar Biol 1:216-225

Reiswig HM (1971) Particle feeding in natural populations of three marine demosponges. Biol Bull 141:568-591

Reiswig HM (1973) Population dynamics of three Jamaican Demospongiae. Bull Mar Sci 23:191-226

Ricciardi A, Bourget E (1998) Weight-to-weight conversion factors for marine benthic macroinvertebrates. Mar Ecol Prog Ser 163:245-251

Riebesell U, Fabry VJ, Hansson L, Gattuso JP (2010) Guide to best practices for ocean acidification research and data reporting. Publications Office of the European Union, Luxembourg

Rosell D, Uriz MJ (1992) Do associated zooxathellae and the nature of the substratum affect survival, attachment and growth of Cliona viridis (Porifera: Hadromerida)? An

Editorial responsibility: Joseph Pawlik, Wilmington, North Carolina, USA experimental approach. Mar Biol 114:503-507

Rützler K (2004) Sponges on coral reefs: a community shaped by competitive cooperation. Boll Musei Istituti Biologici Dell'Universita Genova 68:85-148

Schmahl GP (1990) Community structure and ecology of sponges associated with four southern Florida coral reefs. In: Rützler K (ed) New perspectives in sponge biology. Smithsonian Institution Press, Washington, DC, p 377-383

Sheppard C, Rioja-Nieto R (2005) Sea surface temperature 1871-2099 in 38 cells in the Caribbean region. Mar Environ Res 60:389-396

Smith FGW (1941) Sponge disease in British Honduras, and its transmission by water currents. Ecology 22:415-421

> Southward AJ, Kennicutt MC, Alcalà-Herrera J, Abbiati M and others (1996) On the biology of submarine caves with sulphur springs: appraisal of ${ }^{13} \mathrm{C} /{ }^{12} \mathrm{C}$ ratios as a guide to trophic relations. J Mar Biol Assoc UK 76: 265-285

Sullivan KM, Chiappone M (1992) A comparison of belt quadrat and species presence/absence sampling of stony coral (Scleractinia and Milleporina) and sponges for evaluating species patterning on patch reefs of the Central Bahamas. Bull Mar Sci 50:464-488

Thoms C, Ebel R, Proksch P (2006) Activated chemical defense in Aplysina sponges revisited. J Chem Ecol 32: 97-123

> Van Liedekerke BM, Nelis HJ, Lambert WE, De Leenheer AP (1989) High-performance liquid chromatography of quaternary ammonium compounds on a polystyrenedivinylbenzene column. Anal Chem 61:728-732

Wade BA (1972) A description of a highly diverse soft-bottom community in Kingston Harbour, Jamaica. Mar Biol 13:57-69

Webster NS, Cobb RE, Negri AP (2008) Temperature thresholds for bacterial symbiosis with a sponge. ISME $\mathrm{J} 2$ : 830-842

> Weisz JB, Lindquist N, Martens CS (2008) Do associated microbial abundances impact marine demosponge pumping rates and tissue densities? Oecologia 155: 367-376

- Wilkinson CR, Cheshire AC (1988) Growth rate of Jamaican coral reef sponges after Hurricane Allen. Biol Bull 175: $175-179$

Wulff JL (1984) Sponge-mediated coral reef growth and rejuvenation. Coral Reefs 3:157-163

Wulff JL (1985) Dispersal and survival of fragments of coral reef sponges. Proc 5th Int Coral Reef Symp, Tahiti 5: $119-124$

Wulff JL (1991) Asexual fragmentation, genotype success, and population dynamics of erect branching sponges. J Exp Mar Biol Ecol 149:227-247

> Wulff JL (2006) Resistance vs recovery: morphological strategies of coral reef sponges. Funct Ecol 20:699-708

Zea S (2001) Patterns of sponge (Porifera, Demospongiae) distribution in remote, oceanic reef complexes of the southwestern Caribbean. Rev Acad Colomb Cienc 25: 579-592

Submitted: December 23, 2011; Accepted: May 29, 2012

Proofs received from author(s): August 6, 2012 